\title{
The 5 Money Mistakes That Blindside Entrepreneurs
}

\section{Kimberly Eddleston (Northeastern University)}

\section{KEYWORDS: Leadership, Family Business, financing.}

Whether you are starting a family business or inheriting one, managing finances strategically helps protects both the business and the family. Yet many entrepreneurs start a business without fully understanding the personal financial resources they will need, and run the business without anticipating their future finances. Familybusiness.org Editor Kim Eddleston talks with Nora Yousif, a financial advisor to family businesses, about what owners and families often fail to do...and how it hurts them.

Additional Search Terms: bankruptcy, family business financing, money management, cash flow 